\title{
Characterization of recombinant $B$. abortus strain RB51SOD toward understanding the uncorrelated innate and adaptive immune responses induced by RB51SOD compared to its parent vaccine strain RB51
}

\author{
Jianguo Zhu ${ }^{1,2 \dagger}$, Charles B. Larson ${ }^{1 \dagger}$, Megan Ann Ramaker ${ }^{3}$, Kimberly Quandt $^{4}{ }^{,}$Jered M. Wendte ${ }^{5}$, \\ Kimberly P. Ku ${ }^{1}$, Fang Chen ${ }^{1}$, George W. Jourdian ${ }^{6}$, Ramesh Vemulapalli' ${ }^{7}$, Gerhardt G. Schurig ${ }^{8}$ and \\ Yongqun $\mathrm{He}^{1 *}$ \\ ${ }^{1}$ Unit for Laboratory Animal Medicine, Department of Microbiology and Immunology, University of Michigan Medical School, Ann Arbor, MI, USA \\ ${ }^{2}$ School of Agriculture and Biology, Shanghai Jiaotong University, Shanghai, China \\ ${ }^{3}$ School of Veterinary Medicine, University of Wisconsin-Madison, Madison, WI, USA \\ ${ }^{4}$ College of Veterinary Medicine, Michigan State University, East Lansing, MI, USA \\ ${ }^{5}$ Center for Veterinary Health Sciences, Oklahoma State University, Stillwater, OK, USA \\ ${ }^{6}$ Department of Internal Medicine and Department of Biological Chemistry, University of Michigan Medical School, Ann Arbor, MI, USA \\ ${ }^{7}$ Department of Comparative Pathobiology, School of Veterinary Medicine, Purdue University, West Lafayette, IN, USA \\ ${ }^{8}$ Center for Molecular Medicine and Infectious Diseases, Department of Biomedical Sciences and Pathobiology, VA-MD Regional College of Veterinary Medicine, \\ Virginia Polytechnic Institute and State University, Blacksburg, VA, USA
}

\section{Edited by:}

Thomas A. Ficht, Texas A\&M

University, USA

\section{Reviewed by:}

David O'Callaghan, INSERM, France Jianwu Pei, Texas A\&M University, USA

\section{*Correspondence:}

Yongqun He, Unit for Laboratory Animal Medicine, Department of Microbiology and Immunology, 018 Animal Research Facility, University of Michigan Medical School, 1150 W Medical Dr. Ann Arbor, Ml 48109, USA.

e-mail:yongqunh@umich.edu

† Jianguo Zhu and Charles B. Larson have contributed equally to this work.
Brucella abortus is a Gram-negative, facultative intracellular pathogen for several mammals, including humans. Live attenuated B. abortus strain RB51 is currently the official vaccine used against bovine brucellosis in the United States and several other countries. Overexpression of protective $B$. abortus antigen $\mathrm{Cu} / \mathrm{Zn}$ superoxide dismutase (SOD) in a recombinant strain of RB51 (strain RB51SOD) significantly increases its vaccine efficacy against virulent $B$. abortus challenge in a mouse model. An attempt has been made to better understand the mechanism of the enhanced protective immunity of RB51SOD compared to its parent strain RB51. We previously reported that RB51SOD stimulated enhanced Th1 immune response. In this study, we further found that T effector cells derived from RB51SOD-immunized mice exhibited significantly higher cytotoxic $T$ lymphocyte activity than T effector cells derived from RB51-immunized mice against virulent $B$. abortus-infected target cells. Meanwhile, the macrophage responses to these two strains were also studied. Compared to RB51, RB51SOD cells had a lower survival rate in macrophages and induced lower levels of macrophage apoptosis and necrosis. The decreased survival of RB51SOD cells correlates with the higher sensitivity of RB51SOD, compared to RB51, to the bactericidal action of either Polymyxin B or sodium dodecyl sulfate (SDS). Furthermore, a physical damage to the outer membrane of RB51SOD was observed by electron microscopy. Possibly due to the physical damage, overexpressed Cu/Zn SOD in RB51SOD was found to be released into the bacterial cell culture medium. Therefore, the stronger adaptive immunity induced by RB51SOD did not correlate with the low level of innate immunity induced by RB51SOD compared to RB51. This unique and apparently contradictory profile is likely associated with the differences in outer membrane integrity and Cu/Zn SOD release.

Keywords: Brucella abortus strains RB51 and RB51SOD, Cu/Zn superoxide dismutase (Cu/Zn SOD), innate immunity, adaptive immunity, cytotoxic T lymphocyte (CTL), macrophage cell death, outer membrane integrity, protein release

\section{INTRODUCTION}

Brucella abortus is a Gram-negative, facultative intracellular bacterium that causes brucellosis in humans and many animals (Corbel, 1997). Brucellosis is one of the most common zoonotic diseases. It infects approximately 500,000 humans annually worldwide. The Brucella lack classical virulence factors, such as invasive proteases, exotoxins, capsules, fimbriae, virulence plasmids, and lysogenic phages. The virulence of Brucella relies heavily on their ability to survive and replicate within the vacuolar phagocytic compartments of macrophages (Baldwin and Winter, 1994; Roop et al., 2009). As shown in the mouse model, the ability of different species or strains of Brucella to survive in macrophages in vitro correlates with bacterial virulence in vivo. The virulence of Brucella in vivo and their ability to survive in macrophages in vitro correlates inversely with the innate resistance of the host to brucellosis (Baldwin and Winter, 1994). The treatment of 
brucellosis remains difficult and requires antibiotics that penetrate macrophages and can act in an acidic intracellular environment. Brucella lipopolysaccharide (LPS) is a virulence factor that plays a critical role in macrophage-Brucella interaction (Lapaque et al., 2005). Smooth virulent Brucella strains contain an intact LPS, and are capable of inhibiting programmed cell death in infected human and mouse macrophages (Gross et al., 2000; Tolomeo et al., 2003; He et al., 2006). Rough Brucella strains lack O-antigen or produce extremely low levels of the antigen. Naturally occurring rough $B$. canis and B. ovis strains are pathogenic in their preferred hosts (Carmichael and Bruner, 1968; Rahaley and Dennis, 1984). Some rough $B$. abortus strains have been found to survive and replicate in macrophages (Pei and Ficht, 2004). However, most rough strains of Brucella spp. are attenuated and cannot survive inside macrophages (Fernandez-Prada et al., 2003; Rittig et al., 2003; Pei and Ficht, 2004; Chen and He, 2009; Chen et al., 2011). Cattle brucellosis vaccine strain RB51 is a rough live attenuated $B$. abortus strain derived from smooth virulent strain 2308 (Schurig et al., 2002). A safe, effective human brucellosis vaccine does not exist, but it is needed to increase public health and biosafety. For rational vaccine design, it is important to understand the mechanism underlying protective Brucella immunity.

Cell-mediated immunity (CMI) plays an important role in adoptive protective immunity to brucellosis. A $\mathrm{T}$ helper type 1 (Th1) immune response, indicated by IFN- $\gamma$ production, is required for protective Brucella immunity (He et al., 2001, 2002). Cytotoxic T lymphocyte (CTL) activity is critical for protection against brucellosis (Oliveira and Splitter, 1995; He et al., 2001). RB51 vaccination of mice stimulates a strong Brucella-specific Th1 and CTL response (He et al., 2001). Recently, we reported that RB51, but not its parent wild type strain 2308, induced caspase2-mediated apoptotic and necrotic murine macrophage cell death (Chen and He, 2009). It is suggested that programmed cell death of RB51-infected macrophages results in presentation of RB51 antigens in apoptotic vesicles to dendritic cells (DCs) and further priming of Brucella-specific T cells through a process called "cross-priming" (Yrlid and Wick, 2000; Winau et al., 2005).

The recombinant strain RB51SOD, which overexpresses Brucella $\mathrm{Cu} / \mathrm{Zn}$ superoxide dismutase (SOD) in RB51 (Vemulapalli et al., 2000b), has been reported to induce a specific Th1 type immune response to $\mathrm{Cu} / \mathrm{Zn}$ SOD and to confer enhanced protection against a virulent $B$. abortus challenge (as compared to RB51; Vemulapalli et al., 2002). Brucella Cu/Zn SOD is a periplasmic protein, and an appropriate immune response to this protein confers protection against $B$. abortus challenge in a mouse model (Vemulapalli et al., 2000b; He et al., 2002; Onate et al., 2003). Typically, BALB/c mice vaccinated with strain RB51 do not develop significant levels of antibody or CMI to $\mathrm{Cu} / \mathrm{Zn}$ SOD. However, vaccination with strain RB51SOD stimulates the production of SOD-specific antibodies and an IFN- $\gamma$ response (Vemulapalli et al., 2000b). Since RB51SOD is being tested to replace RB51 as an improved cattle brucellosis vaccine, a large number of studies have been conducted to ascertain why RB51SOD induces an enhanced protection over that obtained with RB51. In order to stimulate a robust adaptive response, a robust innate immune response is usually essential. Surendran et al. recently reported that compared to RB51SOD, RB51 stimulates an enhanced innate immune response in murine bone marrow-derived DCs (Surendran et al., 2010a) and in lung tissue in a mouse model (Surendran et al., 2010b). Particularly, RB51 induced significantly higher DC maturation and function compared to RB51SOD (Surendran et al., 2010a). Compared to RB51SOD, intranasal mouse immunization of RB51 induced: (a) more activated DCs, (b) higher production of cytokines (e.g., TNF- $\alpha$ and IFN- $\gamma$ ) in bronchoalveolar lavage (BAL), and (c) severer interstitial pneumonia in the lungs (Surendran et al., 2010b). The observed apparent dilemma between enhanced protection and a weakened innate immunity in vivo and in DCs induced by RB51SOD is interesting. However, the mechanism under this dilemma is unclear and deserves confirmation and further investigation. Since macrophages are important innate immune cells and the macrophage-Brucella interaction is critical for Brucella pathogenesis, one critical step to understand the dilemma between enhanced protection and weakened innate immunity is to analyze the differences between RB51SOD and RB51 in their interactions with macrophages. Another research approach toward addressing this problem is to analyze the differences of these two strains in biophysical properties and resistance to various bactericidal activities in vitro.

The goal of the present studies was to provide deeper insight into the differential innate and adoptive immune responses induced by RB51SOD versus RB51. We initially demonstrated that RB51SOD induces a higher CTL activity against virulent Brucella infection in vaccinated mice than RB51, which explains the enhanced protection induced by RB51SOD. Secondly, we studied interactions that occurred between RB51SOD/RB51 and macrophages. These studies revealed that compared to RB51, RB51SOD has a reduced survival capability inside macrophages and induces a lower level of macrophage cell death. The reduced survival inside macrophages correlates with the higher sensitivity of RB51SOD to the bactericidal action of either Polymyxin $\mathrm{B}$ or sodium dodecyl sulfate (SDS). The reason for the different sensitivities to the in vitro bactericidal activities is due to a physical damage to the outer membrane of RB51SOD. We also found that overexpressed $\mathrm{Cu} / \mathrm{Zn}$ SOD in RB51SOD is released into the bacterial cell culture medium. It is likely that compared to RB51, the reduced outer membrane integrity (as shown by the increased sensitivity to bactericidal activity of Polymyxin B and SDS) in RB51SOD is associated with the weakened innate immunity induced by RB51SOD. Furthermore, the enhanced protection and adaptive immunity generated by RB51SOD is possibly due to the overexpression of $\mathrm{Cu} / \mathrm{Zn} \mathrm{SOD}$ and its release into extracellular area.

\section{MATERIALS AND METHODS BACTERIAL STRAINS AND MACROPHAGE CELL CULTURE}

All bacterial strains were grown at $37^{\circ} \mathrm{C}$ in tryptic soy broth (TSB) or on tryptic soy agar (TSA; Difco/Becton-Dickinson, Sparks, MD, USA). Studies utilizing live virulent Brucella strain 2308 were performed in a Biosafety level-3 (BSL-3) laboratory. All other studies were conducted in a BSL-2 laboratory. Murine macrophage cell lines J774A.1 (ATCC \#TIB-67) and RAW264.7 (ATCC \#TIB-71) were cultured at $37^{\circ} \mathrm{C}$ in a $5 \% \mathrm{CO}_{2}$ atmosphere in a complete medium (c-DMEM) consisting of Dulbecco's modified Eagle's medium (DMEM; ATCC) supplemented with 10\% 
heat-inactivated fetal bovine serum (HyClone, Logan, UT, USA). Cultured macrophages, passages 3 and 14, were used in these experiments. This study was approved by the University Committee on Use and Care of Animals (UCUCA \#09695) in the University of Michigan.

\section{VACCINATION OF MICE}

Four- to five-week-old female BALB/c mice were purchased from Charles River laboratories (Wilmington, MA, USA). Groups of four mice each were injected intraperitoneally (i.p.) with $\sim 4 \times 10^{8}$ cells (strain RB51 or RB51SOD). Saline served as negative control. The mice, sacrificed at $6-7$ weeks post-vaccination by $\mathrm{CO}_{2}$ inhalation, served as splenocyte sources for the CTL assay.

\section{CYTOTOXIC T LYMPHOCYTE ACTIVITY ANALYSIS}

A neutral red uptake CTL cytotoxicity assay was performed according to a previously described in Section "Materials and Methods" (He et al., 2001). Two mice from each group were sacrificed for each CTL assay. The spleens from each group were pooled, and the splenocytes isolated and passed though nylon wool columns to enrich the T cell population in each preparation. Previous studies indicated processing through nylon wool does not change the ratio of $\mathrm{CD}^{+}$and $\mathrm{CD}^{+} \mathrm{T}$ cells in the splenocytes (He et al., 2001). Viable RB51 cells were used to infect J774.A1 macrophages in a ratio of $100: 1$ for $4-5 \mathrm{~h}$ for preparing stimulator cells. The infected macrophages were incubated at $37^{\circ} \mathrm{C}$ with mitomycin $\mathrm{C}$ $(35 \mu \mathrm{g} / \mathrm{ml})$ for $45 \mathrm{~min}$. The antibiotic was removed by centrifugation at $300 \times g(4 \times)$. The macrophages (stimulator cells) were mixed with enriched T cells in a ratio of 1:10 in 24-well cell culture plates and incubated at $37^{\circ} \mathrm{C}$, under $5 \% \mathrm{CO}_{2}$ for 5 days. The cells were collected and the live effector $\mathrm{T}$ cells purified on a Histopaque column (He et al., 2001). Infected target cells were prepared by infecting J774.A1 macrophages at $37^{\circ} \mathrm{C}$, under $5 \% \mathrm{CO}_{2}$ for $4-5 \mathrm{~h}$ with strain 2308 in a ratio of 100:1. Normal J774.A1 cells served as control target cells. A series of dilutions of effector T cells were performed in 96-well round-bottom cell culture plates in triplicate, and target cells were added at concentrations of 50,000 cells/well. The effector T cells and target cells were incubated at $37^{\circ} \mathrm{C}$, under $5 \% \mathrm{CO}_{2}$ for $16 \mathrm{~h}$. Target cells lacking effector cells served as controls. The culture medium was carefully removed, and $200 \mu \mathrm{l}$ of warm neutral red solution $(0.036 \%)$ were added to each well. Following incubation at $37^{\circ} \mathrm{C}$ for $40 \mathrm{~min}$, the cell monolayers were washed for three times with $37^{\circ} \mathrm{C}$ phosphate-buffered saline $(\mathrm{pH}$ 7.2-7.4), and the cells lysed in $0.05 \mathrm{M}$ acetic acid-0.05\% SDS solution $(220 \mu \mathrm{l} /$ well $)$. Aliquots of $200 \mu \mathrm{l}$ were removed from each well, transferred to 96-well ELISA microplates, and the OD $_{570}$ recorded using an ELISA microplate reader. The percentage of specific lysis was established by applying the formula: specific lysis $=(\mathrm{OD}$ of control - OD of experimental group/OD of control $\times 100$; He et al., 2001).

\section{ANALYSIS OF BRUCELLA SURVIVAL INSIDE MACROPHAGES}

RAW264.7 macrophages were cultured in 24-well plates at $2.5 \times 10^{5}$ cells/well and incubated at $37^{\circ} \mathrm{C}$ overnight. Small volumes of BrucellaRB51 and RB51SOD cultures contained in TSB were diluted in 1:100 and cultured in TSB overnight. Cell numbers were calculated spectrophotometrically. An $\mathrm{OD}_{600}$ of one approximated $3 \times 10^{9}$ Brucella cells (Sun et al., 2005). Macrophages were infected with Brucella at different multiplicities of infection (MOIs). The plates were centrifuged at room temperature for $5 \mathrm{~min}$ at $300 \times \mathrm{g}$. All incubations were conducted at $37^{\circ} \mathrm{C}$ in an atmosphere containing $5 \%$ (vol/vol) $\mathrm{CO}_{2}$. After $1 \mathrm{~h}$ the cells were washed three times with Dulbecco's phosphate-buffered saline (DPBS), and incubated in fresh DMEM supplemented with $50 \mu \mathrm{g} / \mathrm{ml}$ of gentamicin to kill extracellular bacteria. To assess the intracellular survival of Brucella inside macrophages, the cells were lysed with $1 \mathrm{ml}$ of sterile $0.1 \%$ (vol/vol) Triton X-100 at 1,6,24, and $48 \mathrm{~h}$ post infection, respectively. The number of colony forming units (CFUs) was obtained by plating a series of dilutions on TSA plates. All experiments were conducted in biological triplicates, i.e., different replicates using macrophages from different flasks of culture and Brucella cells originating from different Brucella colonies.

\section{DETERMINATION OF PROGRAMMED MACROPHAGE CELL DEATH}

RAW264.7 macrophages were infected using the same protocols described above except that macrophages were cultured in six-well plates at $1 \times 10^{6}$ cells/well. At different time points, apoptotic and necrotic macrophages were detected by staining with Annexin V (green dye) and propidium iodide (PI, red dye) using an Annexin V-FLUOS staining kit (Roche Diagnostics Corporation, Indianapolis, Ind.; Chen and He, 2009). RB51 and RB51SODinfected macrophages were incubated at room temperature for 20 min with Annexin V and PI. Fluorescence was observed with a Nikon TE2000-S microscope. Images were photographed with an RT Side Spot digital camera. Apoptotic and necrotic cell numbers were counted in representative fields containing at least 100 cells.

To quantitate macrophage cell viability, cells infected with RB51 or RB51SOD were cultured in triplicate in 96-well plates (described above). The culture supernatants were collected at varying time points, and the lactate dehydrogenase $(\mathrm{LDH})$ released (used as a viability criteria) quantized with a CytoTox 96 nonradioactive cytotoxicity assay kit (Promega, Madison, WI, USA) according to the manufacturer's instructions (Chen and He, 2009). The percent of dying/membrane-damaged cells was expressed as a percentage of the maximum amount of $\mathrm{LDH}$ released.

\section{ASSAYS FOR BACTERIAL RESISTANCE TO BACTERICIDAL ACTIVITIES BY CHEMICAL DETERGENTS}

The comparative sensitivities of RB51SOD and RB51 to the bactericidal action of Polymyxin $\mathrm{B}(\mathrm{PmB})$ and sodium dodecyl sulfate (SDS) were measured. The PmB sensitivity assay was essentially that of Allen et al. (1998). Specifically, the Brucella were grown to $\log$ phase in TSB, pelleted at $4,200 \times g$, resuspended in $10 \mathrm{mM}$ phosphate buffer ( $\mathrm{pH} 7.2$ ) at approximately $4 \times 10^{4} \mathrm{CFU} / \mathrm{ml}$, and incubated at $37^{\circ} \mathrm{C}$ for $1 \mathrm{~h}$ with several concentrations of $\mathrm{PmB}$ (500, 250, 125 and $62.5,31.25,15,7.5 \mu \mathrm{g} / \mathrm{ml}$, respectively). Following incubation, the cell suspensions were serially diluted (1:10) in $10 \mathrm{mM}$ phosphate buffer ( $\mathrm{pH} 7.2$ ), and $50 \mu \mathrm{l}$ aliquots were plated in triplicate TSA plates. After 4 days of culturing in $37^{\circ} \mathrm{C}$ with $5 \%$ $\mathrm{CO}_{2}$, the colonies on the plates were counted and used to calculate the bacterial CFU under different PmB concentrations. The results of three assays were averaged. The PmB bactericidal activity was expressed as a percentage of the Brucella surviving in wells incubated in the absence of bactericidal agents. To test for SDS 
susceptibility, bacteria were pelleted at $3000 \times g$, washed once in $20 \mathrm{mM}$ Tris-HC1 buffer, $\mathrm{pH} 7.5$, and resuspended in the same buffer to an $\mathrm{OD}_{600}$ approximating 1.0. The cells were incubated at $37^{\circ} \mathrm{C}$ for varying periods of time in $0.3 \%$ SDS, and the decrease in optical density at $600 \mathrm{~nm}$ monitored (Georgiou and Shuler, 1988).

\section{ELECTRON MICROSCOPY}

RB51 and RB51SOD were cultured in TSB to the late log phase. After centrifugation, the cell pellets were fixed for $1 \mathrm{~h}$ in an ice-cold solution of $2.5 \%$ glutaraldehyde and $4 \%$ formaldehyde in $0.1 \mathrm{M}$ isosmotic phosphate buffer, $\mathrm{pH}$ 7.4. The fixative was decanted, and each sample washed for $15 \mathrm{~min}$ with three changes of $0.1 \mathrm{M}$ phosphate buffer. The samples were then fixed at $4^{\circ} \mathrm{C}$ in $1 \% \mathrm{OsO} 4$ contained in $0.1 \mathrm{M}$ phosphate buffer for $1.5 \mathrm{~h}$, washed three times for $15 \mathrm{~min}$ in the same solution and dehydrated with multiple washes in ethanol of decreasing water content. The samples were infiltrated with epoxy resin, and embedded in Spurr medium (Ted Pella Inc., Redding, CA, USA). Ultrathin sections were prepared with a microtome and mounted on copper/rhodium mesh grids M150-CR (Electron Microscopy Sciences, Fort Washington, PA, USA). The grids were stained with uranium acetate and lead citrate and examined in a Philips CM 100 transmission electron microscope (Borisov et al., 2008).

\section{DETECTION OF OVEREXPRESSED SOD RELEASE IN RECOMBINANT STRAIN RB51SOD}

To detect release of SOD from recombinant RB51 strains, strains RB51 and RB51SOD were grown in TSB medium to a cell density of $\sim 5 \times 10^{8}$ cells $/ \mathrm{ml}$. The supernatants from $10 \mathrm{ml}$ of culture were treated with cold trichloroacetic acid (TCA), a final concentration of $20 \%$, incubated at $4^{\circ} \mathrm{C}$ overnight, and centrifuged at $15,000 \times g$ for $30 \mathrm{~min}$ (Metcalf and Wanner, 1993). The pellets were washed with acetone, dissolved in $100 \mu \mathrm{l}$ of Laemmli sample buffer $(2 \times)$, boiled for $5 \mathrm{~min}$, and the protein constituents resolved by SDSPAGE on $12.5 \%$ acrylamide gels (Vemulapalli et al., 2000b). For each sample, $20 \mu \mathrm{l}$ of prepared solution was used in a standard SDS-PAGE experiment (He et al., 2002). The gels were stained with Coomassie brilliant blue R-250 or transferred to polyvinylidene difluoride (PVDF) membranes for Western blot analyses (Chen and $\mathrm{He}, 2009)$.

\section{AMINO ACID SEQUENCING}

The SDS-PAGE gels were electro-transferred to PVDF membranes with CAPS transfer buffer (10 mM 3-[cyclohexylamino]-1propanesulfonic acid, 10\% methanol, pH 11.0; Matsudaira, 1987). The resolved proteins were visualized by staining with Coomassie brilliant blue R-250, destained with 50\% methanol, and washed with distilled water. The membranes were dried and used for analysis of their amino acid sequences by Midwest Analytical, Inc. (St. Louis, MO, USA). The sequences detected were subjected to a BLAST search [National Center for Biotechnology Information (NCBI)] to identify the proteins.

\section{STATISTICAL ANALYSES}

The data from appropriate experiments were analyzed using the Microsoft Excel statistics package. Analysis of variance (ANOVA) or $t$-test was used for statistical analysis of experiments results obtained from various experimental assays.

\section{RESULTS \\ RB51SOD INDUCES A HIGHER LEVEL OF CYTOTOXICITY AGAINST VIRULENT BRUCELLA THAN RB51}

Since the CTL activity is critical to protective Brucella immunity, we hypothesized that in mice RB51SOD would induce a higher level of CTL activity than RB51. To test this hypothesis, the cytolytic ability to lyse virulent Brucella infected target macrophages by effector $\mathrm{T}$ cells from immunized mice was detected using a neutral red uptake assay (He et al., 2001). Neutral red is taken up by viable, infected, or non-infected target macrophages but not by residual live effector cells or dead cells. The ability of B. abortus-specific CTLs from strain RB51 or RB51SODimmunized mice to lyse virulent B. abortus strain 2308-infected or uninfected J774.A1 macrophages was determined (Figure 1). Specific lysis of strain 2308-infected target cells was detected by T effector cells derived from each Brucella strain. Four different effector cell/target cell (E/T) ratios were used. RB51SOD induced significantly greater lysis $(P$-value $<0.05)$ against strain 2308 -infected macrophages than RB51. Only a small level of lysis was observed when the T effector cells were incubated with non-infected J774.A1 macrophages.

\section{DECREASED BRUCELLA SURVIVAL AND DECREASED PROGRAMMED CELL DEATH IN MACROPHAGES INFECTED BY RB51SOD COMPARED TO RB51}

A strong adaptive response usually accompanies a strong innate immune response. The macrophage response is an important

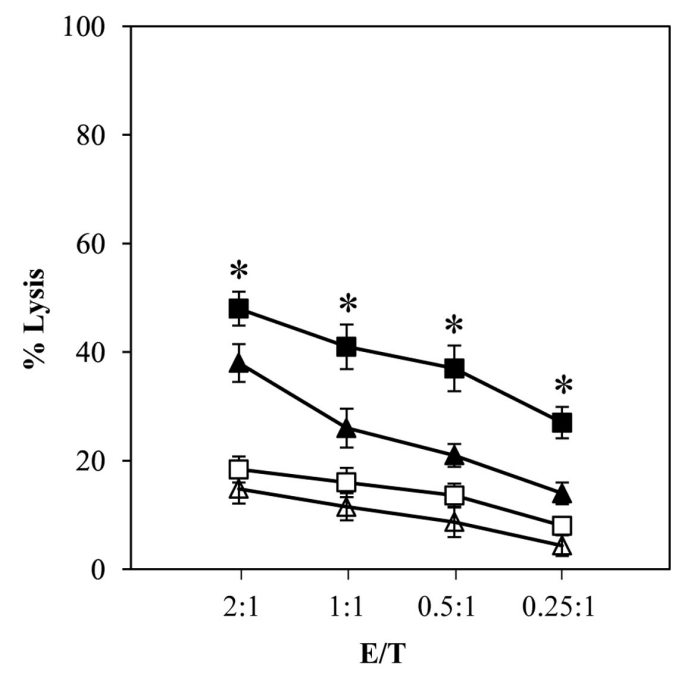

FIGURE 1 | RB51SOD induces greater CTL activity against virulent Brucella-infected macrophage target cells than RB51. T cells were isolated from spleens of BALB/c mice immunized with RB51 (triangles) or RB51SOD (squares). T effector cells were cocultured at various ratios with either virulent strain 2308-infected macrophages (solid triangles and squares) or normal uninfected J774.A1 macrophages (unfilled triangles and squares). CTL cytotoxic activity was measured using the neutral red uptake assay described in Section "Materials and Methods." The data presented are means of triplicate estimations. RB51SOD induced significantly more lysis against strain 2308-infected macrophages than strain RB51

$(P$-value $<0.05)$. The T effector cells derived from saline-injected mice did not lyse any target cells (data not shown). The sign $*$ represents statistical significance $(P$-value $<0.05)$. 
form of innate immunity. The interaction between macrophages and Brucella is key to chronic Brucella infection. To establish whether a possible correlation between innate and adaptive immunities induced by RB51SOD and RB51 exists, we focused our comparative analysis on macrophage responses to RB51SOD and RB51. The kinetic profiles of intracellular survival of Brucella strains RB51 and RB51SOD were analyzed in concert with the cell death of infected macrophages (Figures 24). Macrophages were infected with RB51 or RB51SOD. At $1 \mathrm{~h}$ post infection, the number of RB51 cells found inside the macrophages was similar to that found with RB51SOD. However, at 6 and $24 \mathrm{~h}$ post infection, RB51SOD exhibited a significantly lower number (approximately one Log or 10-fold less) of surviving cells inside macrophages than RB51 $(P$-value $<0.05$; Figure 2).

Our previous study revealed that RB51 induces apoptotic and necrotic cell death in infected macrophages (Chen and He, 2009). We have also found that similar to another rough, live attenuated Brucella strain VTRS1 (Chen et al., 2011), RB51-induced macrophage cell death is proinflammatory (data not shown). This new result suggests that RB51-induced macrophage cell death differs from classical non-proinflammatory apoptosis. It is further hypothesized that RB51-induced macrophage cell death will induce cross-priming that results in Brucella-specific T cell maturation and activation (Chen and He, 2009). Therefore, a possible difference in the level of RB51- or RB51SOD-induced macrophage cell death might lead to induction of different levels of protection against virulent Brucella infections (Vemulapalli et al., 2000b). Based on these phenomena and hypothesis, establishing whether RB51SOD would induce programmed macrophage cell death and to what level was of interest. Lactate dehydrogenase $(\mathrm{LDH})$ release was used to determine the

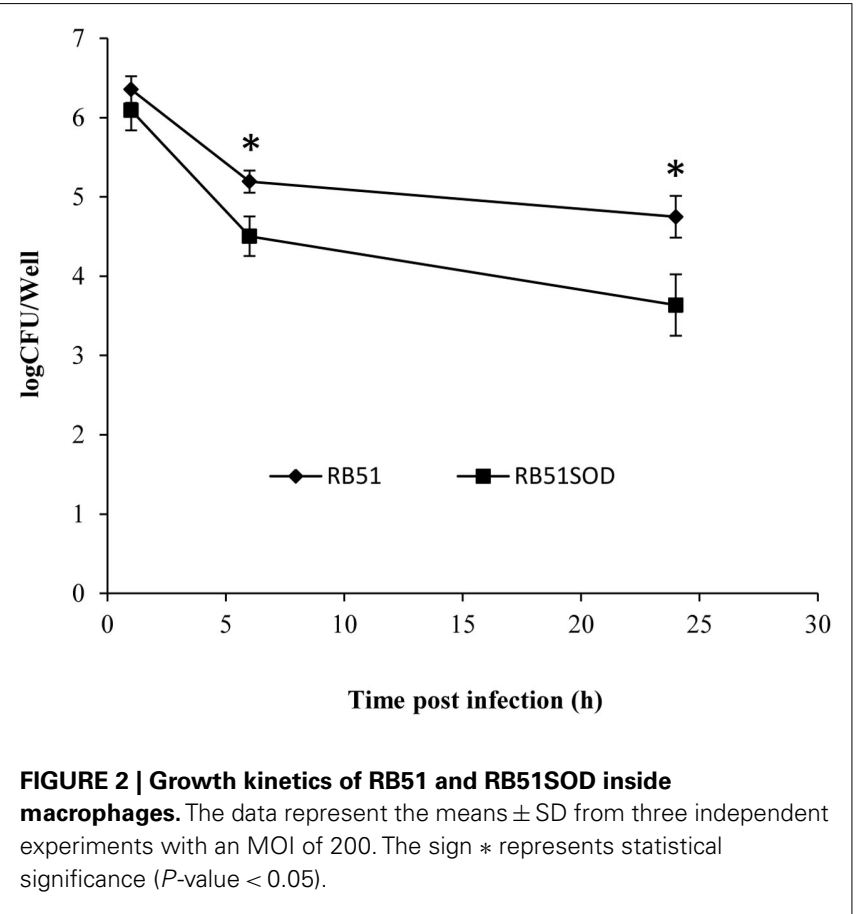

cytopathic effect of RB51SOD or RB51 on infected macrophages. The results of this assay revealed that RB51SOD induced a lower level of cell death than RB51 at $6 \mathrm{~h}$ post infection and remained lower with time $(P$-value $<0.05$; Figure 3$)$. To further analyze the pattern of cell death in Brucella-infected macrophages, infected cells were stained with Annexin V (green) and propidium iodide (PI, red; Chen and He, 2009). The result of fluorescence staining of infected macrophages indicated that rough B. abortus strains RB51 and RB51SOD each exhibited apoptotic (stained green) and necrotic (stained green and red) macrophage cell death. At $24 \mathrm{~h}$ post infection with RB51 and RB51SOD, the cells that underwent either apoptotic or necrotic cell death contained 38.4 and $16.3 \%$ of infected macrophages, respectively (Figure 4). Therefore, compared to RB51SOD, a twofold reduction in cell death was observed in RB51-infected macrophages at $24 \mathrm{~h}$ post infection. These results indicate that RB51SOD induces less programmed cell death of infected macrophages than RB51.

\section{COMPROMISED RESISTANCE OF RB51SOD TO BACTERICIDAL ACTIVITY BY CHEMICAL DETERGENTS}

Why does RB51SOD have a lower survival inside macrophages? The lower survival inside macrophages often correlates with compromised resistance to bactericidal activity induced by chemical detergents. To test this, RB51SOD and RB51wereexposed separately to Polymyxin B sulfate $(\mathrm{PmB})$ or SDS, and the lytic sensitivity to each reagent was determined. Polymyxin B sulfate $(\mathrm{PmB})$, a strongly cationic cyclic polypeptide antibiotic, binds to and neutralizes LPS. Specifically, PmB forms ionic interactions with oligosaccharide components of LPS, including 2-keto-3deoxyoctulosonic acid and phosphate. PmB has been frequently used as a model defensin, a cationic and amphipathic peptide which functions within phagocytic cells (e.g., macrophages) by permeabilizing the cytoplasmic cell membranes of Gram-negative organisms (Allen et al., 1998). PmB has a strong bactericidal

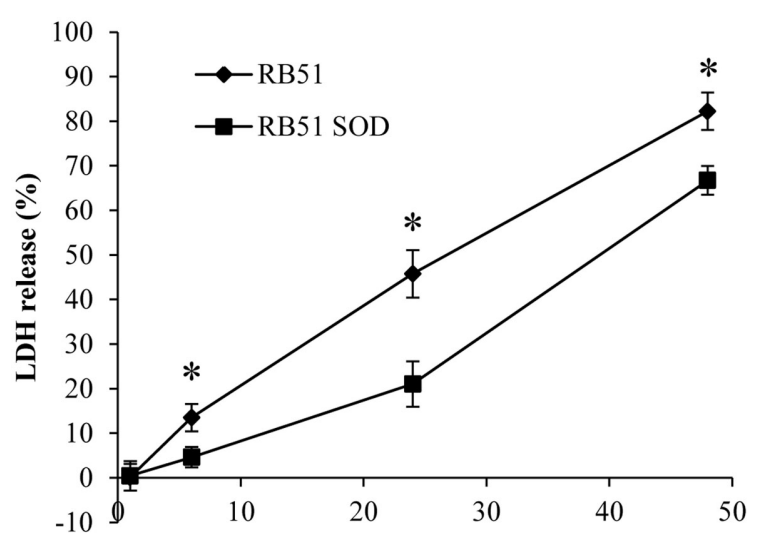

Time post infection (h)

FIGURE 3 | LDH release as a measure of macrophage cell death induced by infection of RB51 or RB51SOD. The data represent the means $\pm S D$ from three independent experiments, each with an $\mathrm{MOI}$ of 200. The sign $*$ represents statistical significance $(P$-value $<0.05)$. 
affect against rough $B$. abortus, reflecting the actions of relevant components of the oxygen-independent systems of phagocytes (Martinez De Tejada et al., 1995). PmB increases the permeability of the outer membrane of Gram-negative bacteria (Vaara, 1992). Differential resistances of Brucella strains to the PmB bactericidal activity also indicate different outer membrane integrities. When PmB was used, RB51SOD survival as measured by CFU counts was reduced relative to that observed with RB51 over a
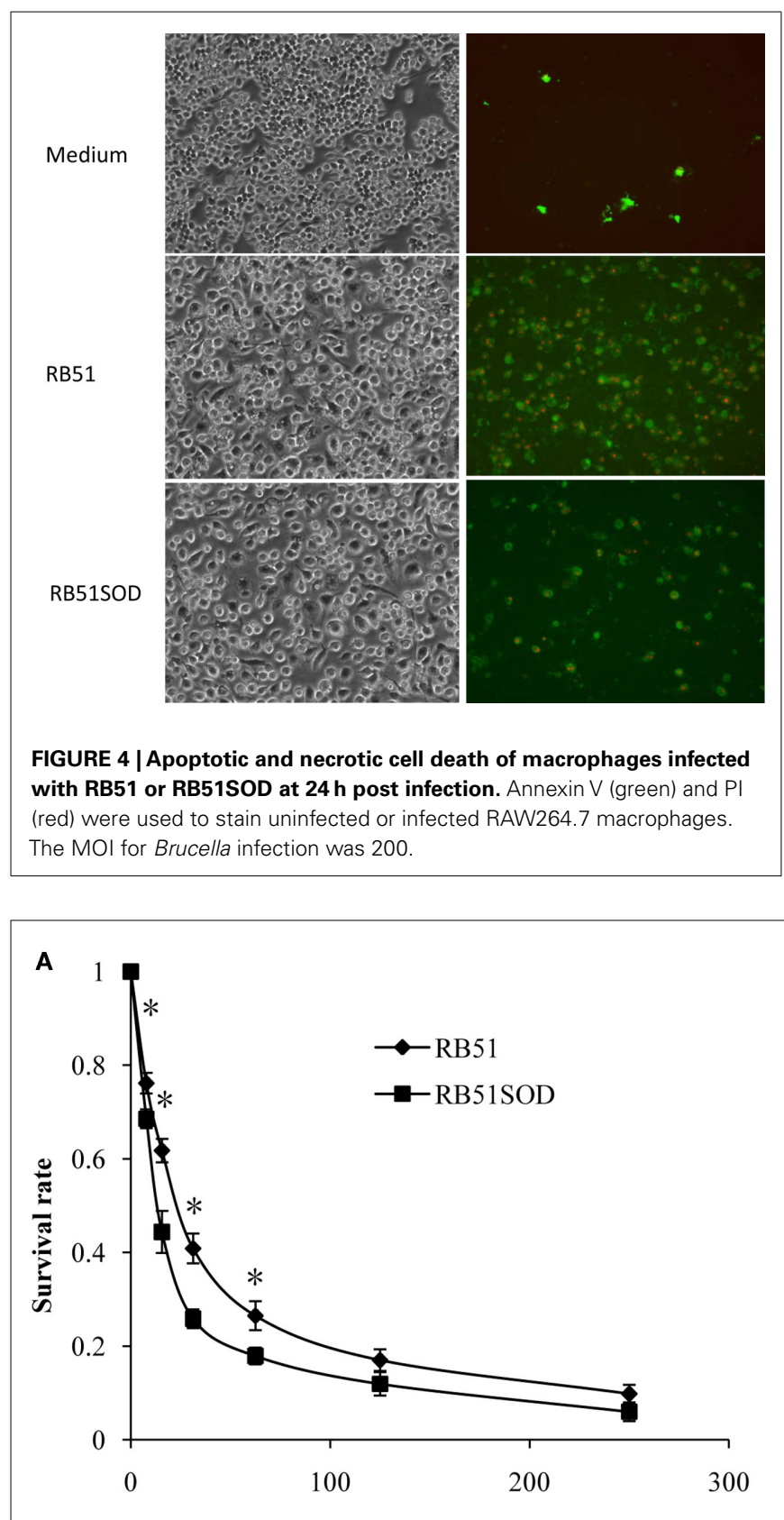

Polymyxin B concentration $(\mu \mathrm{g} / \mathrm{ml})$
PmB concentration range of 7.5-500 $\mu \mathrm{g} / \mathrm{ml}$. RB51SOD exhibited greater sensitivity $(P$-value $<0.05)$ to $\mathrm{PmB}$ at all tested concentrations below $100 \mu \mathrm{g} / \mathrm{ml}$ (Figure 5A). For example, with a PmB concentration of $31.25 \mu \mathrm{g} / \mathrm{ml}$, approximately $41 \%$ of RB51 cells survived inside macrophages; however, only $26 \%$ of RB51SOD cells survived. This is an approximately 1.6 fold reduction in terms of bacterial survival inside macrophages.

Sodium dodecyl sulfate (SDS) is an anionic surfactant and amphiphilic detergent that has frequently been used in testing bacterial resistance to lytic activity and bacterial outer membrane integrity (Georgiou and Shuler, 1988). Similarly to PmB, RB51SOD also showed a greater sensitivity to the bacteriolytic activity of SDS (Figure 5B) at different time points within $80 \mathrm{~min}$. For example, at $80 \mathrm{~min}$ after exposure to $0.3 \%$ of SDS, the OD600 value of RB51 and RB51SOD suspensions were approximately 0.8 and 0.65 , respectively. This is approximately $15 \%$ of reduction in OD600 value. Considering the dead bacteria also contribute to OD value, more than $15 \%$ of live bacterial reduction likely occurred at this condition. Overall, the results indicate that the RB51SOD cells were lysed faster than RB51 by SDS (Figure 5B).

\section{DAMAGED OUTER MEMBRANE INTEGRITY OF RB51SOD CELLS}

The increased sensitivity of RB51SOD over that of RB51 to PmB and SDS suggests that the integrity of the outer membrane of RB51SOD is compromised. To test a possible physical damage of RB51SOD outer membranes, transmission electron microscope analysis was performed (Figure 6). Approximately 5-10\% of RB51SOD cells exhibited "physical damage.” In contrast, no physical damage was observed in RB51 samples (Figure 6A). Large gaps of the cell membrane and obvious membrane damage were observed on the surface of RB51SOD cells in log phase growth (Figures 6B,C). This phenomenon differs from outer membrane "vesicle blebs" which are usually small and do not disrupt the cell membrane (Kuehn and Kesty, 2005).

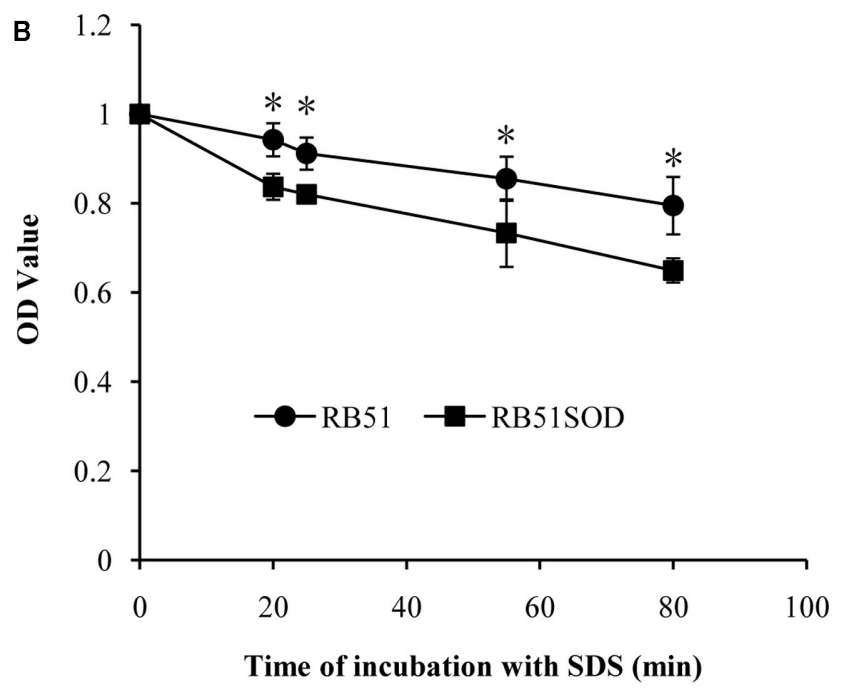

(B) Decrease in $\mathrm{OD}_{600}$ after Brucella exposure to $0.3 \%$ SDS for increasing periods of time. The sign $*$ represents statistical significance $(P$-value $<0.05)$. 

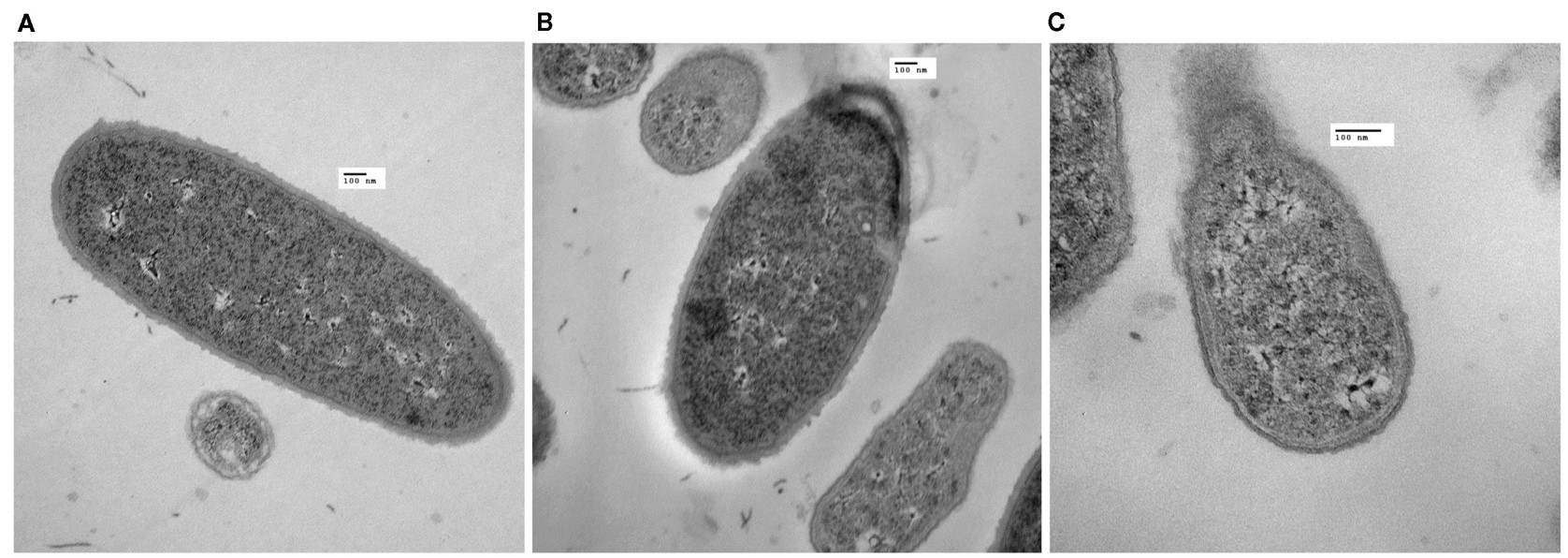

FIGURE 6 | Electron microscopy of RB51 and RB51SOD outer membrane damage. RB51 lacked outer membrane damage (A). Outer membrane damage appeared on the surface of RB51SOD (B,C). The scale bar represents a length of $100 \mathrm{~nm}$.

\section{RELEASE OF OVEREXPRESSED SOD BY RECOMBINANT STRAIN RB51S0D}

The compromised integrity of the outer membrane may lead to release of periplasmic proteins. Overexpression of $\mathrm{Cu} / \mathrm{Zn} \mathrm{SOD}$ in the recombinant strain RB51SOD has been documented in previous studies (Vemulapalli et al., 2000b, 2002). An elevated level of $\mathrm{Cu} / \mathrm{Zn}$ SOD protein is present inside intact RB51SOD cells compared to the level found in RB51 (Vemulapalli et al., 2000b, 2002). To further test whether overexpressed $\mathrm{Cu} / \mathrm{Zn}$ SOD is released from inside RB51SOD cells, culture supernatants of recombinant strain RB51SOD and RB51 were precipitated with TCA. The precipitate were subjected to SDS-PAGE and stained with Coomassie blue (Figure 7A). The precipitates from recombinant strain RB51SOD migrated as a single protein that comigrated with authentic SOD, and exhibited an approximate molecular mass of $16 \mathrm{kDa}$ (Figure 7A). The protein also reacted with antiSOD antibodies on Western blot analysis (Figure 7B). No proteins that reacted with anti-SOD antibodies were present in the TCA precipitated culture supernatant of strain RB51.

The release of $\mathrm{Cu} / \mathrm{Zn} \mathrm{SOD}$ into the culture supernatant of strain RB51SOD was confirmed by subjecting the protein contained on the PVDF membrane to amino acid sequencing. The first 10 amino acids from the N-terminal end of the protein had the sequence: ESTTVKMYEA. This sequence is identical to the sequence reported for $B$. abortus $\mathrm{Cu} / \mathrm{Zn}$ SOD in the NCBI protein database (NCBI RefSeq number YP_418725.1 and UniProt Accession number P15453). A bioinformatics analysis revealed that the N-terminal signal sequence: MKSLFIASTMVLMAFPAFA had been cleaved. This cleavage accounts for the approximately $2 \mathrm{kDa}$ difference between the molecular weights of the released protein we observed in this study and the Brucella $\mathrm{Cu} / \mathrm{Zn}$ SOD including the signal sequence (Vemulapalli et al., 2000b).

To assess if the release of overexpressed proteins in recombinant Brucella RB51 strains is a general phenomenon, similar analyses were performed on TCA precipitates of recombinant RB51 strains overexpressing the homologous Brucella cytosolic antigens GroEL and GroES. Neither of the two overexpressed proteins was released into the extracellular medium (data not shown). Taken together,

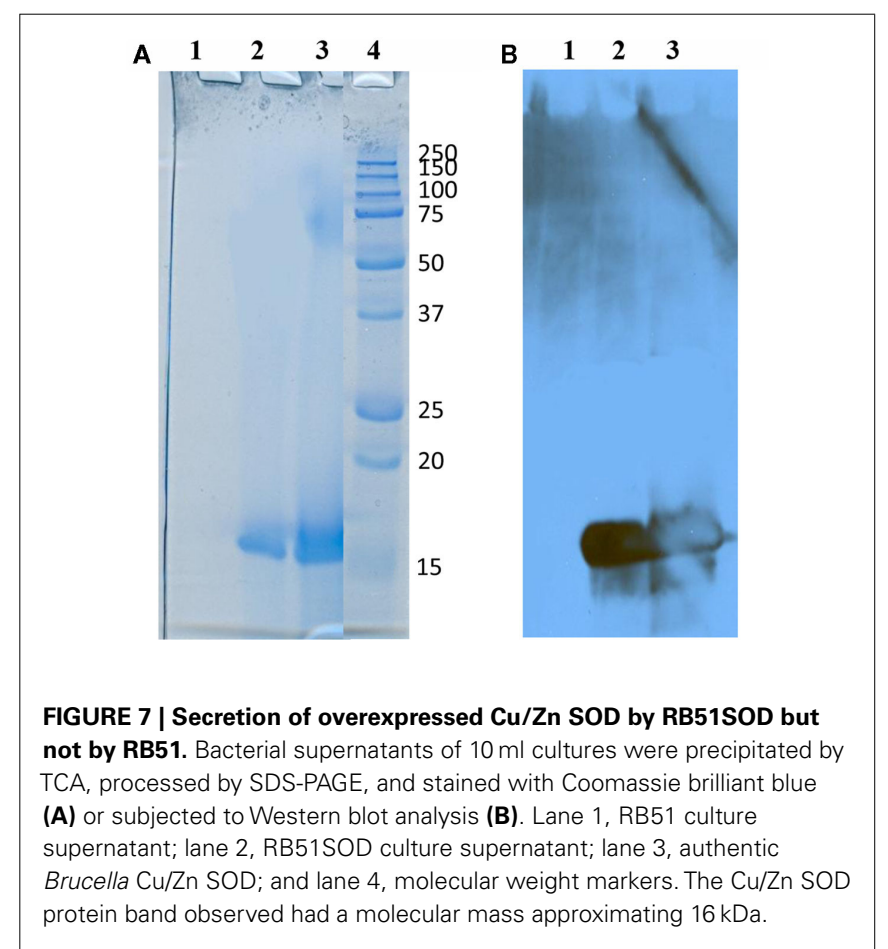

the above results suggest that release of $\mathrm{Cu} / \mathrm{Zn} \mathrm{SOD}$ in recombinant RB51 strains is restricted to overexpressed periplasmic or outer membrane proteins.

\section{DISCUSSION}

There is no safe and effective Brucella vaccine available for human use. Because of its enhanced vaccine efficacy RB51SOD has been tested as a possible cattle vaccine candidate to replace RB51. An in depth investigation of the mechanism of RB51SOD-induced enhanced protection will enhance our understanding of protective Brucella immunity and lend support to a rational vaccine design for developing a safe and effective Brucella vaccine in humans. This study provided new data for characterization of RB51SOD 
in an effort to better understand uncorrelated innate and adaptive immune responses induced by RB51SOD and RB51. Specifically, as expected, RB51SOD induces an enhanced Th1 immune response (Vemulapalli et al., 2000b) and CTL activity (Figure 1) compared to RB51. However, RB51SOD has decreased survival in macrophages and is less efficient in inducing macrophage cell death than RB51. During attempts to clarify this phenomenon, it became apparent that RB51SOD has a compromised resistance to bactericidal activity and physical outer membrane damage that lead to the release of overexpressed periplasmic $\mathrm{Cu} / \mathrm{Zn} \mathrm{SOD}$.

Previous studies demonstrated that RB51SOD induces strong Th1 immune responses as indicated by the induction of a high level of interferon- $\gamma$ (IFN- $\gamma$ ) production (Vemulapalli et al., 2000b). However, not all Brucella antigens that induce a Th1 type of immune response are capable of generating protective immunity. For example, Brucella heat shock proteins (HSPs) such as GroEL and HtrA induced strong Th1 type of immune responses with high IFN- $\gamma$ production, but cannot induce protective immunity against virulent Brucella challenges (Bae et al., 2002; Leclerq et al., 2002). B. abortus YacD also induces IFN- $\gamma$ production but no protection against virulent Brucella (Vemulapalli et al., 1998). Indeed, as a critical adaptive immunity, CTL activity appears to have a better correlation with protective Brucella immunity (He et al., 2001). Therefore, we performed a CTL activity assay to compare the adaptive immune responses induced by these two strains against virulent Brucella infections. Our study indicated that RB51SOD induces a stronger CTL response against virulent $B$. abortus-infected macrophage target cells than the nonoverexpressing strain RB51 (Figure 1). The enhanced CTL activity induced by RB51SOD is critical for enhanced vaccine protection induced by RB51SOD. Previous studies have demonstrated that Brucella sodC encoded in DNA vaccine (Munoz-Montesino et al., 2004), in an RNA vaccine (Onate et al., 2005), or in a fused to IL-2 (Gonzalez-Smith et al., 2006) was able to induce Brucella $\mathrm{Cu} / \mathrm{Zn}$ SOD-specific CTL activity against Brucella-infected target cells. Interestingly, live RB51SOD was used in all these studies to infect macrophages for generation of stimulator cells in the CTL assays. Our result is consistent with those shown in these studies, suggesting that RB51SODinduces SOD-specific CTL activity.

Surendran et al. reported that RB51SOD stimulates a lower innate immune response in lungs after intranasal immunization in vivo (Surendran et al., 2010b) and in murine bone marrowderived DCs compared to RB51(Surendran et al., 2010a). Since macrophages are important innate immune cells that interact with Brucella at an early stage in infection (Baldwin and Winter, 1994), we focused our analysis on the interactions between macrophages and these two Brucella strains. We discovered the reduced survival of RB51SOD inside macrophages, which may result in decreased innate immune responses in vivo in other tissues (e.g., lung) and cells (e.g., DCs) as well. The reduced survival of RB51SOD inside macrophages appears to result from RB51SOD outer membrane damage. Due to the RB51SOD outer membrane damage, RB51SOD becomes more sensitive than RB51 to bactericidal action of Polymyxin B (a cationic polypeptide antibiotic) and to SDS (a detergent; Figure 5). This finding may explain the reduced capability of RB51SOD to resist various brucellacidal mechanisms in macrophages (Baldwin and Winter, 1994) than RB51 and may lead to its decreased level of survival inside macrophages (Figure 2). All these further explain the reduced innate immunity induced by RB51SOD compared to RB51. It is noted that our previous study (Vemulapalli et al., 2000a) and another independent report (Allen et al., 1998) have indicated that wild type strain 2308 (the parent strain of RB51) is resistant to the bactericidal activity of Polymyxin $\mathrm{B}$. These confirmed the importance of intact $\mathrm{O}$-antigen to Brucella resistance to bactericidal activity of chemical detergents. More studies are also deserved to identify the differences of RB51SOD and RB51 in vivo in a real life immunization scenario, including their serum sensitivity.

The RB51-induced programmed macrophage cell death may release apoptotic vesicles that contain Brucella antigens that activate $\mathrm{DCs}$ and $\mathrm{CD} 8^{+} \mathrm{T}$ cells. This process of $\mathrm{CD} 8^{+} \mathrm{T}$ cell activation is called "cross-priming." The cross-priming process presents antigens acquired from outside the cell (Bevan, 2006). This detour pathway differs from the classical MHC class I antigen presentation pathway (or called endogenous pathway) that presents intracellular antigens (e.g., antigens synthesized by viruses or intracellular bacteria inside cells) to MHC class I molecules. Cross-priming can be initiated through apoptotic macrophages induced by Salmonella (Yrlid and Wick, 2000), M. tuberculosis (Winau et al., 2005), and influenza virus (Albert et al., 1998). We found that RB51SOD-induced less macrophage cell death probably due to the compromised resistance to macrophage bactericidal killing and reduced survival of RB51SOD inside macrophages. It is hypothesized that RB51 activates CTL activity by cross-priming (Chen and $\mathrm{He}, 2009)$. If this is the case, the reduced macrophage cell death and decreased Brucella survival inside macrophages will not lead to an enhanced cross-priming process and, therefore, cannot explain the enhanced protection induced by RB51SOD. Therefore, other possible mechanism(s) are likely to exist in the induction of enhanced protective immunity.

It is interesting to note that overexpressed $\mathrm{Cu} / \mathrm{Zn} \mathrm{SOD}$ is released from RB51SOD (Figure 7). Overexpression of recombinant periplasmic proteins such as PhoS, $\beta$-Lactamase, and cytochrome $b_{5}$ in E. coli results in their release (Pages et al., 1987; Georgiou and Shuler, 1988; Kaderbhai et al., 1997). Many Brucella proteins have been found to be secreted or released from live Brucella species in vitro or in vivo. For example, Caron et al. (1996) reported that an unidentified protein-like molecule(s) was "secreted" into the culture medium of B. suis. The protein exhibited inhibitory activity against TNF- $\alpha$ production in human macrophages. Boigegrain et al. (2004) reported that at $\mathrm{pH} 4.0$ in minimal medium or citrate buffer, B. suis was able to secrete periplasmic proteins through the blebbing of the outer cell membrane. Recently, Brucella protein RicA was identified to be a secreted effector that interacts with human small GTPase Rab2 (De Barsy et al., 2011). Many secreted Brucella proteins are regulated by Brucella Type IV secretion systems (Marchesini et al., 2004; De Jong et al., 2008; Delpino et al., 2009). VceA and VceC, members of the $\mathrm{VjbR}$ regulon, were found to be translocated into macrophages through the Brucella type IV secretion system (De Jong et al., 2008). Delpino et al. (2009) found 11 Brucella proteins secreted to culture supernatants in wild type Brucella but not in a virB10 mutant. To the best of our knowledge, the release of overexpressed SOD from strain RB51SOD is the first demonstration of a Brucella protein released by Brucella cells overexpressing a periplasmic protein. This release is likely due to the physical 
damage occurring in the RB51SOD outer membrane (Figure 6). However, it remains to be determined whether this release effect is specific to the overexpression of periplasmic $\mathrm{Cu} / \mathrm{Zn}$ SOD.

Since the release of overexpressed $\mathrm{Cu} / \mathrm{Zn} \mathrm{SOD}$ is a phenomenon associated with RB51SOD but not with RB51, it is interesting to suggest that there may exist a possible relation between its release and its enhanced vaccine efficacy. A number of reports suggest that the secretory, or released proteins, of intracellular bacterial pathogens are superior protective antigens since they are released to cytosol inside antigen presenting cells (e.g., macrophages) and processed through the classical MHC class I antigen presentation pathway, which in turn leads to the stimulation of protective $\mathrm{CD}^{+}$cytotoxic T cells (Hess et al., 1996, 1997; Harty and Bevan, 1999; Grode et al., 2001). For example, secreted antigens of Mycobacterium tuberculosis and Listeria monocytogenes, rather than constitutive or stress proteins, have been found to be superior protective antigens (Orme, 1988, 1997). Shen et al. (1998) demonstrated effective CD8 ${ }^{+}$T cell-dependent immunity to recombinant L. monocytogenes (rLM) expressing a model $\mathrm{CD}^{+} \mathrm{T}$ cell epitope from the nucleoprotein of lymphocytic choriomeningitis virus (LCMV) in secreted form but not against rLM expressing the same epitope in non-secreted form. Interestingly, when a recombinant Salmonella typhimurium aroA vaccine strain was constructed so as to secrete Listeria SOD (a non-secretory protein in wild type Listeria), protection against

\section{REFERENCES}

Albert, M. L., Sauter, B., and Bhardwaj, N. (1998). Dendritic cells acquire antigen from apoptotic cells and induce class I-restricted CTLs. Nature 392, 86-89.

Allen, C. A., Adams, L. G., and Ficht, T. A. (1998). Transposon-derived Brucella abortus rough mutants are attenuated and exhibit reduced intracellular survival. Infect. Immun. 66, 1008-1016.

Bae, J. E., Schurig, G. G., and Toth, T. E. (2002). Mice immune responses to Brucella abortus heat shock proteins. Use of baculovirus recombinantexpressing whole insect cells, purified Brucella abortus recombinant proteins, and a vaccinia virus recombinant as immunogens. Vet. Microbiol. 88, 189-202.

Baldwin, C. L., and Winter, A. J. (1994). Macrophages and Brucella. Immunol. Ser. 60, 363-380.

Bevan, M. J. (2006). Cross-priming. Nat. Immunol. 7, 363-365.

Boigegrain, R. A., Salhi, I., AlvarezMartinez, M. T., Machold, J., Fedon, Y., Arpagaus, M., Weise, C., Rittig, M., and Rouot, B. (2004). Release of periplasmic proteins of Brucellasu is upon acidic shock involves the outer membrane protein Omp25. Infect. Immun. 72, 5693-5703.

Borisov, A. B., Ushakov, A. V., Zagorulko, A. K., Novikov, N. Y., Selivanova, K. F., Edwards, C. A., and Russell, M. W. (2008). Intracardiac lipid accumulation, lipoatrophy of muscle cells and expansion of myocardial infarction in type 2 diabetic patients. Micron 39, 944-951. W. (1968). Characteristics of a newly-recognized species of Brucella responsible for infectious canine abortions. Cornell Vet. 48, 579-592.

Caron, E., Gross, A., Liautard, J. P., and Dornand, J. (1996). Brucella species release a specific, protease-sensitive, inhibitor of TNF-alpha expression, active on human macrophage-like cells. J. Immunol. 156, 2885-2893.

Chen, F., Ding, X., Ding, Y., Xiang, Z., Li, X., Ghosh, D., Schurig, G. G., Sriranganathan, N., Boyle, S. M., and He, Y. (2011). Proinflammatory caspase2-mediated macrophage cell death induced by a rough attenuated Brucella suis Strain. Infect. Immun. 79, 2460-2469.

Chen, F., and He, Y. (2009). Caspase-2 mediated apoptotic and necrotic murine macrophage cell death induced by rough Brucella abortus. PLoS ONE 4, e6830. doi:10.1371/journal.pone.0006830

Corbel, M. J. (1997). Brucellosis: an overview. Emerging Infect. Dis. 3, 213-221.

De Barsy, M., Jamet, A., Filopon, D., Nicolas, C., Laloux, G., Rual, J. F., Muller, A., Twizere, J. C., Nkengfac, B., Vandenhaute, J., Hill, D. E., Salcedo, S. P., Gorvel, J. P., Letesson, J. J., and De Bolle, X. (2011). Identification of a Brucella spp. secreted effector specifically interacting with
Carmichael, L. E., and Bruner, D.

a lethal $L$. monocytogenes challenge was obtained (Hess et al., 1997). In contrast, a S. typhimurium aroA vaccine expressing a non-secretory form of the listerial SOD was unable to induce protection against lethal listeriosis. Therefore, it is likely that the enhanced protection induced by RB51SOD is induced by the release of overexpressed Brucella $\mathrm{Cu} / \mathrm{Zn}$ SOD into macrophage cytosol and the processing of this released protective antigen by macrophages through the classical MHC class I antigen presentation pathway (instead of cross-priming), leading to the priming of Brucella-specific CTL. However, current data does not support the association between the $\mathrm{Cu} / \mathrm{Zn}$ SOD release and its processing through MHC class I antigen presentation pathway. Further investigation is required to substantiate such an association.

\section{ACKNOWLEDGMENTS}

This project was supported by NIAID-NIH R-21 grants AI076812 and AI057875 and to Yongqun He. We would like to acknowledge the contributions of Megan Ann Ramaker, Kimberly Quandt, and Jered M. Wendte whose externship in our lab was funded by the University of Michigan Unit for Laboratory Animal Medicine and the American Society of Laboratory Animal Practitioners Foundation. Kimberly P. Ku was supported by the Undergraduate Research Opportunity Program (UROP) at the University of Michigan.

human small GTPase Rab2. Cell Microbiol. 13, 1044-1058.

De Jong, M. F., Sun, Y. H., Den Hartigh, A. B., Van Dijl, J. M., and Tsolis, R. M. (2008). Identification of VceA and VceC, two members of the VjbR regulon that are translocated into macrophages by the Brucella type IV secretion system. Mol. Microbiol. 70, 1378-1396.

Delpino, M. V., Comerci, D. J., Wagner, M. A., Eschenbrenner, M., Mujer, C. V., Ugalde, R. A., Fossati, C. A., Baldi, P. C., and Delvecchio, V. G. (2009). Differential composition of culture supernatants from wildtype Brucella abortus and its isogenic virB mutants. Arch. Microbiol. 191, 571-581.

Fernandez-Prada, C. M., Zelazowska, E. B., Nikolich, M., Hadfield, T. L., Roop, R. M. II., Robertson, G. L., and Hoover, D. L. (2003). Interactions between Brucella melitensis and human phagocytes: bacterial surface O-Polysaccharide inhibits phagocytosis, bacterial killing, and subsequent host cell apoptosis. Infect. Immun. 71, 2110-2119.

Georgiou, G., and Shuler, M. L. (1988). Release of periplasmic enzymes and other physiological effects of beta-lactamase overproduction in Escherichia coli. Biotechnol. Bioeng. 32, 741-748.

Gonzalez-Smith, A., Vemulapalli, R., Andrews, E., and Onate, A. (2006). Evaluation of Brucella abortus DNA vaccine by expression of $\mathrm{Cu}-\mathrm{Zn}$ superoxide dismutase antigen fused to IL-2. Immunobiology 211, 65-74.

Grode, L., Kaufmann, S. H., and Hess, J. (2001). Contribution of MHC class I-dependent immune mechanisms induced by attenuated recombinant Salmonella typhimurium secreting superoxide dismutase to protection against murine listeriosis. Vaccine 19, 3269-3272.

Gross, A., Terraza, A., OuahraniBettache, S., Liautard, J. P., and Dornand, J. (2000). In vitro Brucella suis infection prevents the programmed cell death of human monocytic cells. Infect. Immun. 68, 342-351.

Harty, J. T., and Bevan, M. J. (1999). Responses of $\mathrm{CD}^{+} \mathrm{T}$ cells to intracellular bacteria. Curr. Opin. Immunol. 11, 89-93.

He, Y., Reichow, S., Ramamoorthy, S., Ding, X., Lathigra, R., Craig, J. C., Sobral, B. W., Schurig, G. G., Sriranganathan, N., and Boyle, S. M. (2006). Brucella melitensis triggers time-dependent modulation of apoptosis and down-regulation of mitochondrion-associated gene expression in mouse macrophages. Infect. Immun. 74, 5035-5046.

He, Y., Vemulapalli, R., and Schurig, G. G. (2002). Recombinant Ochrobactrum anthropi expressing Brucella abortus $\mathrm{Cu}, \mathrm{Zn}$ superoxide dismutase protects mice against B. abortus infection only after switching of immune responses to Th1 type. Infect. Immun. 70, 2535-2543. 
He, Y., Vemulapalli, R., Zeytun, A., and Schurig, G. G. (2001). Induction of specific cytotoxic lymphocytes in mice vaccinated with $\mathrm{Bru}$ cella abortus RB51. Infect. Immun. 69, 5502-5508.

Hess, J., Dietrich, G., Gentschev, I., Miko, D., Goebel, W., and Kaufmann, S. H. (1997). Protection against murine listeriosis by an attenuated recombinant Salmonella typhimurium vaccine strain that secretes the naturally somatic antigen superoxide dismutase. Infect. Immun. 65, 1286-1292.

Hess, J., Gentschev, I., Miko, D., Welzel, M., Ladel, C., Goebel, W., and Kaufmann, S. H. (1996). Superior efficacy of secreted over somatic antigen display in recombinant Salmonella vaccine induced protection against listeriosis. Proc. Natl. Acad. Sci. U.S.A. 93, 1458-1463.

Kaderbhai, N., Karim, A., Hankey, W., Jenkins, G., Venning, J., and Kaderbhai, M. A. (1997). Glycineinduced extracellular secretion of a recombinant cytochrome expressed in Escherichia coli. Biotechnol. Appl. Biochem. 25, 53-61.

Kuehn, M. J., and Kesty, N. C. (2005). Bacterial outer membrane vesicles and the host-pathogen interaction. Genes Dev. 19, 2645-2655.

Lapaque, N., Moriyon, I., Moreno, E., and Gorvel, J. P. (2005). Brucella lipopolysaccharide acts as a virulence factor. Curr. Opin. Microbiol. 8, 60-66.

Leclerq, S., Harms, J. S., Rosinha, G. M., Azevedo, V., and Oliveira, S. C. (2002). Induction of a th1-type of immune response but not protective immunity by intramuscular DNA immunisation with Brucella abortus GroEL heat-shock gene. J. Med. Microbiol. 51, 20-26.

Marchesini, M. I., Ugalde, J. E., Czibener, C., Comerci, D. J., and Ugalde, R. A. (2004). N-terminalcapturing screening system for the isolation of Brucella abortus genes encoding surface exposed and secreted proteins. Microb. Pathog. 37, 95-105.

Martinez De Tejada, G., PizarroCerda, J., Moreno, E., and Moriyon, I. (1995). The outer membranes of Brucella spp. are resistant to bactericidal cationic peptides. Infect. Immun. 63, 3054-3061.

Matsudaira, P. (1987). Sequence from picomole quantities of proteins electroblotted onto polyvinylidene difluoride membranes. J. Biol. Chem. 262, 10035-10038.

Metcalf, W. W., and Wanner, B. L. (1993). Mutational analysis of an Escherichia coli fourteen-gene operon for phosphonate degradation, using TnphoA' elements. J. Bacteriol. 175, 3430-3442.

Munoz-Montesino, C., Andrews, E., Rivers, R., Gonzalez-Smith, A., Moraga-Cid, G., Folch, H., Cespedes, S., and Onate, A. A. (2004). Intraspleen delivery of a DNA vaccine coding for superoxide dismutase (SOD) of Brucella abortus induces SOD-specific $\mathrm{CD}^{+}$and $\mathrm{CD}^{+} \mathrm{T}$ cells. Infect. Immun. 72, 2081-2087.

Oliveira, S. C., and Splitter, G. A. (1995). $\mathrm{CD}^{+}$type 1 CD44hi CD45 RBlo $\mathrm{T}$ lymphocytes control intracellular Brucella abortus infection as demonstrated in major histocompatibility complex class I- and class IIdeficient mice. Eur. J. Immunol. 25, 2551-2557.

Onate, A. A., Cespedes, S., Cabrera, A., Rivers, R., Gonzalez, A., Munoz, C., Folch, H., and Andrews, E. (2003). A DNA vaccine encoding $\mathrm{Cu}, \mathrm{Zn}$ superoxide dismutase of Brucella abortus induces protective immunity in $\mathrm{BALB} / \mathrm{c}$ mice. Infect. Immun. 71, 4857-4861.

Onate, A. A., Donoso, G., MoragaCid, G., Folch, H., Cespedes, S., and Andrews, E. (2005). An RNA vaccine based on recombinant Semliki Forest virus particles expressing the $\mathrm{Cu}$, $\mathrm{Zn}$ superoxide dismutase protein of Brucella abortus induces protective immunity in $\mathrm{BALB} / \mathrm{c}$ mice. Infect. Immun. 73, 3294-3300.

Orme, I. M. (1988). Induction of nonspecific acquired resistance and delayed-type hypersensitivity, but not specific acquired resistance in mice inoculated with killed mycobacterial vaccines. Infect. Immun. 56, 3310-3312.

Orme, I. M. (1997). Progress in the development of new vaccines against tuberculosis. Int. J. Tuberc. Lung Dis. 1, 95-100.

Pages, J. M., Anba, J., and Lazdunski, C. (1987). Conditions leading to secretion of a normally periplasmic protein in Escherichia coli. J. Bacteriol. 169, 1386-1390.

Pei, J., and Ficht, T. A. (2004). Brucella abortus rough mutants are cytopathic for macrophages in culture. Infect. Immun. 72, 440-450.

Rahaley, R. S., and Dennis, S. M. (1984). Histopathology of experimental brucellosis in rams following vaccination with Brucella ovis. Aust. Vet. J. 61, 353-356.

Rittig, M. G., Kaufmann, A., Robins, A., Shaw, B., Sprenger, H., Gemsa, D., Foulongne, V., Rouot, B., and Dornand, J. (2003). Smooth and rough lipopolysaccharide phenotypes of Brucella induce different intracellular trafficking and cytokine/chemokine release in human monocytes. J. Leukoc. Biol. $21,21$.

Roop, R. M. II., Gaines, J. M., Anderson, E. S., Caswell, C. C., and Martin, D. W. (2009). Survival of the fittest: how Brucella strains adapt to their intracellular niche in the host. Med. Microbiol. Immunol. 198, 221-238.

Schurig, G. G., Sriranganathan, N., and Corbel, M. J. (2002). Brucellosis vaccines: past, present and future. Vet. Microbiol. 90, 479-496.

Shen, H., Miller, J. F., Fan, X., Kolwyck, D., Ahmed, R., and Harty, J. T. (1998). Compartmentalization of bacterial antigens: differential effects on priming of CD8 T cells and protective immunity. Cell 92, 535-545.

Sun, Y., Den Hartigh, A. B., Tsolis, R. M., and Ficht, T. A. (2005). "Laboratory maintenance of Brucella abortus," in Current Protocols in Microbiology, eds. R. Coico, T. Kowalik, J. Quarles, B. Stevenson, and R. Taylor (Hoboken, NJ: John Wiley \& Sons, Inc.), 3B.1.1-3B.1.11.

Surendran, N., Hiltbold, E. M., Heid, B., Sriranganathan, N., Boyle, S. M., Zimmerman, K. L., Makris, M. R. and Witonsky, S. G. (2010a). Live Brucella abortus rough vaccine strain RB51 stimulates enhanced innate immune response in vitro compared to rough vaccine strain RB51SOD and virulent smooth strain 2308 in murine bone marrow-derived dendritic cells. Vet. Microbiol. 147, 75-82.

Surendran, N., Zimmerman, K., Seleem, M. N., Sriranganathan, N., Boyle, S. M., Hiltbold, E. M., Lawler, H., Heid, B., and Witonsky, S. G. (2010b). Ability of Brucella abortus rough vaccine strains to elicit DC and innate immunity in lung using a murine respiratory model. Vaccine 28, 7009-7015.

Tolomeo, M., Di Carlo, P., Abbadessa, V., Titone, L., Miceli, S., Barbusca, E., Cannizzo, G., Mancuso, S., Arista, S., and Scarlata, F. (2003). Monocyte and lymphocyte apoptosis resistance in acute and chronic brucellosis and its possible implications in clinical management. Clin. Infect. Dis. 36, 1533-1538.

Vaara, M. (1992). Agents that increase the permeability of the outer membrane. Microbiol. Rev. 56, 395-411.

Vemulapalli, R., Duncan, A. J., Boyle, S. M., Sriranganathan, N., Toth, T. E., and Schurig, G. G. (1998). Cloning and sequencing of yajC and secD homologs of Brucella abortus and demonstration of immune responses to YajC in mice vaccinated with B. abortus RB51. Infect. Immun. 66, 5684-5691.

Vemulapalli, R., He, Y., Buccolo, L. S., Boyle, S. M., Sriranganathan, N., and Schurig, G. G. (2000a). Complementation of Brucella abortus RB51 with a functional wboA gene results in $\mathrm{O}$ antigen synthesis and enhanced vaccine efficacy but no change in rough phenotype and attenuation. Infect. Immun. 68, 3927-3932.

Vemulapalli, R., He, Y., Cravero, S., Sriranganathan, N., Boyle, S. M., and Schurig, G. G. (2000b). Overexpression of protective antigen as a novel approach to enhance vaccine efficacy of Brucella abortus strain RB51. Infect. Immun. 68, 3286-3289.

Vemulapalli, R., He, Y., Sriranganathan, N., Boyle, S. M., and Schurig, G. G. (2002). Brucella abortus RB51: enhancing vaccine efficacy and developing multivalent vaccines. Vet. Microbiol. 90, 521-532.

Winau, F., Hegasy, G., Kaufmann, S. H., and Schaible, U. E. (2005). No life without death - apoptosis as prerequisite for T cell activation. Apoptosis 10, 707-715.

Yrlid, U., and Wick, M. J. (2000). Salmonella-induced apoptosis of infected macrophages results in presentation of a bacteria-encoded antigen after uptake by bystander dendritic cells. J. Exp. Med. 191, 613-624.

Conflict of Interest Statement: The authors declare that the research was conducted in the absence of any commercial or financial relationships that could be construed as a potential conflict of interest.

Received: 30 June 2011; accepted: 09 November 2011; published online: 25 November 2011.

Citation: Zhu J, Larson CB, Ramaker $M A$, Quandt $K$, Wendte $J M, K u K P$, Chen F, Jourdian GW, Vemulapalli $R$, Schurig GG and He Y (2011) Characterization of recombinant B. abortus strain RB51SOD toward understanding the uncorrelated innate and adaptive immune responses induced by RB51SOD compared to its parent vaccine strain RB51. Front. Cell. Inf. Microbio. 1:10. doi: $10.3389 /$ fcimb.2011.00010

Copyright (c) 2011 Zhu, Larson, Ramaker, Quandt, Wendte, Ku, Chen, Jourdian, Vemulapalli, Schurig and He. This is an open-access article distributed under the terms of the Creative Commons Attribution Non Commercial License, which permits use, distribution, and reproduction in other forums, provided the original authors and source are credited. 